\title{
Coronavirus pandemic stirs fight over abortion rights in US
}

\author{
Republican leaders in eight US states are trying to ban abortions in response to the coronavirus \\ pandemic, Janice Hopkins Tanne reports
}

\author{
Janice Hopkins Tanne journalist
}

New York, USA

Texas has allowed medical and surgical abortions to go ahead after a long running court fight during which abortion was repeatedly forbidden and permitted, to the frustration and dismay of doctors and patients.

On 22 March, the governor of Texas, Greg Abbott, signed an executive order banning non-essential medical procedures. Abortions were considered non-essential. The state attorney general, Ken Paxton, said criminal penalties and fines would be imposed on medical professionals for providing abortions and claimed that elective medical procedures used medical supplies needed by doctors and nurses dealing with covid-19. ${ }^{1}$

When the ban expired on 22 April the governor issued a new order that allowed procedures without which patients would "be at risk of serious adverse medical consequences" so long as the procedures did not limit hospital capacity or deplete supplies of protective equipment for doctors and nurses caring for patients with covid-19.

Abortion providers interpreted the new ruling to mean they could now provide both medical and surgical abortions. In a joint statement, the heads of three Planned Parenthood affiliates in Texas said, "Our number one priority is Planned Parenthood patients, and we want them to know that abortion care has been fully restored in Texas. We know that the past month has been devastating and stressful for patients who have been forced to either delay or travel out of state to access time-sensitive, essential abortion care. In the midst of a global health pandemic, patients have been forced to deal with a crisis within a crisis."

The states of Alabama, Arkansas, Iowa, Louisiana, Ohio, Oklahoma, Tennessee also issued bans. (In the US, states can regulate abortions.) Except for Arkansas, where a ban is still in effect, these other bans have been partly or completely suspended by the courts, but the situation remains in flux.

From the start, the Texas action dismayed patients and doctors. Amna Dermish, an obstetrician-gynaecologist with Planned Parenthood in Texas wrote in the Washington Post soon after the initial announcement. "The desperation, fear, and anger we heard from [our patients] was visceral ... Texas is forcing patients to travel out of state, if they can, and try to get abortions there." Patients told her about plans to fly to Colorado or New Mexico, or drive overnight to other states, exposing themselves and others to the virus. ${ }^{2}$

In Texas, a state the size of France with a population of 29 million, there were 55440 abortions in $2017,{ }^{3}$ nearly all carried out in clinics separate from hospitals. For years the state has been a leader in limiting abortion by decreasing funding and increasing restrictions on patients and providers.

Before the governor's order banning abortions, nearly half of Texas counties were more than 100 miles $(160 \mathrm{~km})$ from the nearest abortion provider. ${ }^{4}$

\section{Organisations object}

Medical associations representing nearly one million healthcare providers nationally opposed the Texas ban. The American College of Obstetricians and Gynecologists, the American Medical Association, the American Academy of Family Physicians, and other groups say abortion is an essential, time sensitive, and safe part of healthcare and there is no justification for the governor's order. They say the ban would not increase the burden on hospitals treating covid-19 patients. ${ }^{5}$ Opponents of the ban note that legal abortion has been shown to be safer than childbirth. ${ }^{6}$

Cost is a big impediment to abortion in the US. Many state medical programmes for poor people do not include abortions, which are usually provided in freestanding clinics at a cost of \$500-\$700 ( $£ 404-£ 567$; $€ 464-€ 650$ ) for medical abortions, and more for surgical abortions during the first trimester. Many employer health insurance plans don't cover abortion either-a moot point for the women who have lost their jobs as a result of the economic crisis caused by covid- 19 .

Bhavik Kumar, a family physician with Planned Parenthood in Houston, Texas, told The BMJ it was frustrating to practise medicine while the ban was fought in the courts. "I can't see patients at all. Then I can. Anyway there's the mandatory 24 hour delay [between first consultation and procedure]. I see patients [for the first consultation] and then [when the courts 
step in again] I can't see them for the second consultation. We have the expertise, the staff, but we can't do it because of politicians. It's the uncertainty." He said doctors are angry, confused, and frustrated.

Many of Kumar's patients were waiting and hoping for better court rulings, using Google Alerts to find clinics in nearby states and telephoning for appointments. Clinics in nearby states have seen a more than sevenfold increase in patients from Texas, according to Planned Parenthood. ${ }^{7}$

He says some have driven 10 hours to out-of-state clinics only to find them closed or not accepting new patients. Others have tried to buy the pills needed for a medical abortion online, but supplies from Indian drug companies were limited by the pandemic. He said it was common for patients to tell him they had tried herbs or illegal methods before coming to his clinic.

The situation is especially difficult for teenagers, who require parental consent for an abortion. A client services manager for Jane's Due Process, a non-profit organisation that helps young women navigate Texas's parental consent laws, told

Rewire.News, "One [young woman], already the parent of a toddler, said she cannot risk contracting covid-19 to leave the state for abortion care .... Another ... told me that her grandmother, who is also her caretaker and immunocompromised because of her age, isn't able to travel with [her] out of fear of contracting covid-19."»
Competing interests: I have read and understood BMJ policy on declaration of interests and have no relevant interests to declare.

Provenance and peer review: Commissioned; not externally peer reviewed.

Abbot G. Executive order No GA09 relating to hospital capacity during the Covid-19 disaster, 22 Mar 2020. https://lrl.texas.gov/scanned/govdocs/Greg\%20Abbott/2020/GA09.pdf

2 Dermish A. Texas banned me from providing abortions-using coronavirus as an excuse. Washington Post 20204 Apr. www.washingtonpost.com/outlook/2020/04/04/texas-abortionban-coronavirus/

3 Guttmacher Institute. State facts about abortion. 2020. www.guttmacher.org/fact-sheet/ state-facts-about-abortion-texas

4 White K, Sierra G, Vizcarra E, et al. The potential impacts of Texas' executive order on patients' access to abortion care. Texas Policy Evaluation Project, University of Texas at Austin. Research Brief, March 2020

5 American College of Obstetricians and Gynecologists. ACOG leads coalition of nearly 1 million medical professionals to oppose Texas restrictions on abortion during the COVID-19 pandemic. Press release, 2 Apr 2020. www.acog.org/news/news-releases/2020/04/ medical-professionals-to-oppose-texas-abortion-restrictions

6 Raymond EG, Grimes DA. The comparative safety of legal induced abortion and childbirth in the United States. Obstet Gynecol 2012;119:215-9.

10.1097/AOG.0b013e31823fe923 22270271

7 McCammon S. After Texas abortion ban, clinics in other southwestern states see influx of patients. NPR $2020 \mathrm{Apr}$ 17. www.npr.org/sections/coronavirus-live-updates/2020/04/ 17/837153529/after-texas-abortion-ban-clinics-in-neighboring-states-see-influx-of-patients

8 Garcia IL. This is how Texas' covid-19 abortion ban uniquely burdens teens. Rewire. News 2020 Apr 9. https://rewire.news/article/2020/04/09/this-is-how-texas-covid-19-abortionban-uniquely-burdens-teens

Published by the BMJ Publishing Group Limited. For permission to use (where not already granted under a licence) please go to http://group.bmj.com/group/rights-licensing/ permissions 